\title{
KEBIASAAN OLAH RAGA BERPENGARUH TERHADAP TINGKAT STRESS MAHASISWA POLTEKKES KEMENKES JAKARTA III
}

\author{
Ricca Andalasari, Abdurahman Berbudi BL \\ UIN Syarif Hidayatullah Jakarta \\ Poltekkes Kemenkes Jakarta III \\ ricca.md@gmail.com
}

\begin{abstract}
Health is somethingthat everyone needs, but with a solid activity we sometimes forget to maintain health, and more often ignore it. To maintain health we must do exercise, good exercise will increase endorphin hormone, and decrease cortisol, which affects a person's stress level, good exercise habits will decrease a person's stress level. The purpose of this study is to determine the relationship of exercise habits to stress levels of the students Poltekkes Kemenkes Jakarta III. Sampling Method using purposive random sampling, and the design study used is crossectional design. There were 100 students participated in tjis study. The results of this study found that exercise habits of stress levels have a high relationship, and significant influence where obtained $p$ value $<0.05$. This shows that good sports habits affect the level of stress in students Poltekkes Kemenkes Jakarta III.
\end{abstract}

Keywords: Sports Habits, Sex, Stress

\begin{abstract}
ABSTRAK
Kesehatan merupakan sesuatu yang dibutuhkan setiap orang, namun dengan aktivitas yang padat terkadang kita lupa dalam menjaga kesehatan, dan lebih sering mengabaikannya. Untuk menjaga kesehatan kita harus berolahraga, olahraga yang baik akan meningkatkan hormone endorfin, dan menurunkan kortisol, dimana hal ini berdampak pada tingkat stress seseorang, kebiasaan olahraga yang baik akan menurunkan tingkat stress seseorang. Tujuan dari penelitian ini adalah untuk mengetahui hubungan kebiasaan olahraga terhadap tingkat stress pada mahasiswa Poltekkes Kemenkes Jakarta III. Proses pengambilan sampel adalah menggunakan purposive sampling, dan desain penelitian yang digunakan adalah crossectional. 100 orang berpartisipasi pada penelitian ini. Hasil penelitian ini didapatkan bahwa kebiasaan olahraga terhadap tingkat stress mempunyai hubungan yang tinggi, dan pengaruh yang signifikan dimana didapatkan nilai $p<0.05$. hal ini menunjukkan bahwa kebiasaan olahraga yang baik berrpengaruh terhadap tingkat stress pada mahasiswa Poltekkes Kemenkes Jakarta III.
\end{abstract}

Kata Kunci : Kebiasaan Olahraga, Jenis Kelamin, Stres

\section{PENDAHULUAN}

Kesehatan merupakan dambaan setiap orang yang tidak bisa diukur dengan uang, namun dengan aktivitas yang padat terkadang kita lupa dalam menjaga kesehatan, dan lebih sering mengabaikannya. Cara menjalankan pola hidup sehat sebenarnya mudah, sederhana 
dan membutuhkan waktu sebentar setiap harinya untuk dilakukan. Kita sebagai manusia hanya perlu memperhatikan halhal kecil setiap harinya dan jika diperlukan kita dapat merubahnya supaya lebih bermanfaat bagi kesehatan tubuh.Memiliki badan sehat tidak hanya tubuh saja, tetapi jiwa. Sehat sebenarnya tidak harus selalu mengeluarkan biaya yang besar. Namun faktanya, banyak orang rela mengeluarkan biaya besar untuk menjaga penampilan dan kesehatan tubuhnya. Olahraga salah satunya untuk menjaga kesehatan (Raiola G et al., 2014)

Olahraga telah lama sudah menjadi kebutuhan bagi masyarakat secara luas. Terbukti dengan bertumbuhnya pusat kesehatan dan olahraga serta dipenuhinya ruang-ruang publik pada hari libur oleh masyarakat yang ingin berolahraga agar jiwa dan raganya sehat. Hal ini menunjukkan bahwa olahraga bukan hanya sekedar kebutuhan, tetapi telah menjadi gaya hidup. Pada umumnya masyarakat melakukan olahraga untuk menjaga kebugaran tubuh serta menjaga kesehatan agar dapat menjalankan aktivitas sehari-hari dengan fit, akan tetapi tidak sedikit juga mereka yang melakukannya karena hobi atau mengejar prestasi pada ajang atau event kelohragaan.
Olahraga yang baik yaitu kegiatan olahraga yang dilakukan dengan intensitas secara teratur dan berkelanjutan. Sedangkan submaksimal yang dimaksud yaitu tidak ada forcing kemampuan individu melebih batas kemampuannya tersebut baik dalam beban maupun intensitasnya. Tidak hanya terpusat pada kesehatan jasmani, olahraga untuk kesehatan ini juga baik manfaatnya bagi kesehatan rohani serta kehidupan sosial individu tersebut karena selain aman, mudah dan murah, olahraga ini dapat dilakukan kapanpun dan dimanapun secara massal (Kenari, M.A. 2014).

Berdasarkan data yang didapat dari (Riskesdas 2013) diketahui Proporsi penduduk yang melakukan aktivitas fisik "aktif" dan "kurang aktif". Proporsi aktivitas fisik yang tergolong kurang aktif secara umum adalah 26,1 persen dari total proporsi penduduk rata-rata di Indonesia. Dari total keseluruhan provinsi terdapat kurang lebih 22 provinsi dengan penduduk aktivitas fisik tergolong kurang aktif berada diatas rata-rata Indonesia. Lima provinsi tertinggi diantaranya provinsi DKI Jakarta (44,2\%), Papua (38,9\%), Papua Barat (37,8\%), Sulawesi Tenggara dan Aceh (masing-masing 37,2\%).

Benefit saat olahraga yang dilakukan cukup dan teratur telah sudah lama tersebar luas dan diinformasikan 
diberbagai media secara luas dalam berbagai artikel kesehatan maupun artikel populer serta jurnal kesehatan. Diantaranya manfaat yang diperoleh meliputi, olahraga dapat mencegah terjadinya obesitas, stress, diabetes, hyperlipidemia, stroke, penyakit jantung, dan hipertensi. Bahkan dalam penelitiannya di belgia Veronique dan Robert (2005) menyimpulkan bahwa latihan atau kegiatan olahraga aerobic dapat diterapkan sebagai manajemen hipertensi tidak hanya untuk pencegahan.

Stres yaitu ketidakmampuan emosi seseorang dalam mengatasi ancaman yang dihadapi oleh mental, fisik, emosional, dan spiritual manusia, yang pada kemudian hari dapat mempengaruhi kesehatan fisik dan rohani manusia tersebut. Stres normal merupakan reaksi alamiah pada tubuh yang berguna, karena stres akan meningkatkan kemampuan seseorang untuk mengatasi kesulitan atau beban kehidupan. Pekerjaan dan persaingan yang banyak, tuntutan, dan tantangan dalam dunia modern saat ini, menjadi tekanan dan beban stress (ketegangan) bagi setiap orang. Stressor yang terlampau besar hingga melampaui batas ambang daya tahan individu, dapat menimbulkan gejalagejala seperti sakit kepala, gampang marah, psikis dan sulit tidur(NguyenMichel et al, 2006). Stres yang telah berlangsung lama, tubuh akan berusaha mengadakan adaptasi sehingga timbul perubahan patologis pada penderita. Penderita stres pada saat ini semakin marak, diperkirakan 1,33 juta jiwa penduduk DKI Jakarta diperkirakan mengalami gangguan kesehatan mental atau stres. Gangguan stress dapat disebabkan berbagai hal, yaitu karena masalah pekerjaan dan tata ruang kota yang buruk dan kondisi lalu lintas yang macet kian hari kian meningkat intensitasnya di provinsi DKI Jakarta.

Angka tersebut mencapai $14 \%$ dari total penduduk dengan tingkat stres akut (stres berat) mencapai 1-3\%. Data Dinas Kependudukan dan Catatan Sipil DKI Jakarta menunjukkan jumlah penduduk DKI Jakarta saat ini mencapai 9,5 juta jiwa. Jumlah penduduk yang stres mencapai 1,33 juta (14 persen dari 9,5 juta), sementara stres berat mencapai 95.000-285.000 orang (1-3 persen dari 9,5 juta) (PDKI 2012).

Berdasarkan Riskesdas tahun 2013, Prevalensi gangguan mental emosional (Stress) penduduk Indonesia berdasarkan Riskesdas 2007 adalah 11,6 persen dan bervariasidiantaraprovinsidankabupaten /kota.

\section{METODE}

Penelitian ini menggunakan desain crossectional dengan menganalisis secara empiris tentang pengaruh kebiasaan olahraga terhadap tingkat stress pada mahasiswa Poltekkes Kemenkes Jakarta 
III. Pengujian hipotesis dan analisis dilakukan pada variabel independen yaitu kebiasaan olahraga dan variabel dependen berupa tingkat stress.

Teknik sampling yang digunakan adalah Proporsional sampling dengan random sampling adalah salah satu teknik pengambilan sampel yang sering digunakan dalam penelitian.

Dari hasil perhitungan maka sampel yang didapat adalah 100 subjek penelitian. Penelitian ini dilaksanakan di Poltekkes Kemenkes Jakarta III di Arteri JORR Jatiwarna Bekasi pada bulan MeiNovember 2017.

\section{HASIL DAN PEMBAHASAN}

Berdasarkan data statistik demografi yang dimiliki oleh Poltekkes Kemenkes Jakarta
III pada tahun 2017 diketahui jumlah populasi mahasiswa adalah kurang lebih 1000 mahasiswa, dimana sampel yang digunakan bersumber dari mahasiswa jurusan fisioterapi berjumlah 233 orang. Sampel dipilih dikarenakan jumlah populasi laki-laki lebih dominan sehingga factor kebiasaan olahraga lebih tinggi.

\section{Deskripsi Responden}

Menurut Sugiyono (2010) gambaran responden, merupakan deskripsi responden yang akan diukur nilai yang akan diteliti. Deskripsi responden dibagi berdasarkan jenis kelamin, tingkat kebiasaan olahraga, tingkat stress mahasiswa pada saat menghadapi ujian, dan tidak sedang ujian.

Tabel 1. Karakteristik Usia

\begin{tabular}{lll}
\hline Karakteristik & Mean \pm SD & Min-max \\
\hline Usia & $20.48 \pm$ & $18-22$ \\
$(\mathbf{n}=\mathbf{1 0 0})$ & 0.87 & \\
\hline
\end{tabular}

Berdasarkan tabel diatas dapat diketahui rerata usia responden adalah 20.48 dengan nilai standart deviasi adalah 0.87 hal ini menunjukkan keragaman responden tidak terlalu tinggi dikarenakan rentang usia mahasiswa hanya terpaut selisih 5 tahun hal ini ditunjukkan dengan nilai minimum usia 18 tahun dan maksimum 22 tahun.

Tabel 2. Karakteristik Jenis Kelamin

\begin{tabular}{lcc}
\hline \multicolumn{3}{l}{ Tabel 2 Karakteristik Jenis Kelamin } \\
\hline $\begin{array}{lcc}\text { Jenis Kelamin } \\
\text { Laki-laki }\end{array}$ & 21 & $(21 \%)$ \\
\hline Perempuan & 79 & $(79 \%)$ \\
\hline Total & 100 & $(100 \%)$ \\
\hline
\end{tabular}


Berdasarkan tabel 2. dapat diketahui jumlah responden laki-laki berjumlah 21 orang $(21 \%)$ dan perempuan berjumlah 79 orang $(79 \%)$ dari jumlah total responden berjumlah 100 orang, dengan demikian responden perempuan lebih mendominasi dibandingkan laki-laki.

Tabel 3. Karakteristik Keibasaan Olahraga Saat Ujian dan Perkuliahan

\begin{tabular}{|c|c|}
\hline \multicolumn{2}{|c|}{ Karakteristik Kebiasaan Olahraga } \\
\hline Ujian & Perkuliahan \\
\hline Karakteristik & Karakteristik \\
\hline Tidak Pernah & Tidak Pernah \\
\hline+2.94 & Jarang \\
\hline Sering & Sering \\
\hline Sangat Sering & Sangat Sering \\
\hline \multirow{4}{*}{$\begin{array}{l}\text { Berdasarkan tabel diatas dapat diketahui } \\
\text { responden yang tidak pernah berolahraga } \\
\text { pada saat ujian dan perkuliahan tidak ada } \\
\text { sama sekali, kebiasaan olahraga yang }\end{array}$} & \multirow{4}{*}{$\begin{array}{l}\text { yang jarang pada saat ujian berjumlah } 11 \\
\text { orang, sering } 40 \text { orang, dan sangat sering } \\
49 \text { orang dengan rerata } 22.87 \text { dengan } \\
\text { standart deviasi } 2.79 \text { dimana hal ini }\end{array}$} \\
\hline & \\
\hline & \\
\hline & \\
\hline jarang pada saat ujian berjumlah 14 orang, & \multirow{4}{*}{$\begin{array}{l}\text { menunjukkan adanya peningkatan jumlah } \\
\text { yang berolahraga, dikarenakan pada saat } \\
\text { ini mahasiswa tidak begitu disibukkan } \\
\text { dengan tugas dan ujian semester. }\end{array}$} \\
\hline sering 41 orang, dan sangat sering 45 & \\
\hline orang dengan rerata 22.57 dengan standart & \\
\hline deviasi 2.94 dimana hal ini menunjukkan & \\
\hline kebiasaan olahraga sering. Sedangkan & \\
\hline & \\
\hline
\end{tabular}

Tabel 4. Karakteristik Tingkat Stress Saat Ujian dan Perkuliahan

\begin{tabular}{|c|c|c|c|c|c|}
\hline \multicolumn{6}{|c|}{ Karakteristik Tingkat Stress } \\
\hline \multicolumn{3}{|c|}{ Ujian } & \multicolumn{3}{|c|}{ Perkuliahan } \\
\hline Karakteristik & (\% & $\begin{array}{l}\text { Mean } \pm \\
\text { SD }\end{array}$ & Karakteristik & $(\%)$ & $\begin{array}{l}\text { Mean } \\
+ \text { SD }\end{array}$ \\
\hline$<14$ tidak ada kecemasan & 71 & $12.12 \pm$ & $<14$ tidak ada kecemasan & 68 & 11.75 \\
\hline $14-20=$ kecemasan ringan & 18 & 5.11 & $14-20=$ kecemasan ringan & 29 & \pm \\
\hline $21-27=$ kecemasan sedang & 11 & & $21-27=$ kecemasan sedang & 3 & 4.59 \\
\hline $28-41=$ kecemasan berat & 0 & & $28-41=$ kecemasan berat & 0 & \\
\hline $42-56=$ kecemasan berat & 0 & & $42-56=$ kecemasan berat sekali & 0 & \\
\hline
\end{tabular}

Dari hasil tabel diatas didapatkan karakteristik responden dengan tingkat sekali, dan kecemasan berat tidak ada yang stress yang mengalami kecemasan berat mengalami pada saat ujian maupun 
perkuliahan, kecemasan sedang pada saat ujian berjumlah 11 orang, ringan 18 orang, dan tidak ada kecemasan 71 orang dengan rerata 12.12 dengan standart deviasi 5.11 dimana hal ini menunjukkan tidak adanya kecemasan yang tinggi pada mahasiswa jurusan fisioterapi poltekkes Kemenkes Jakarta III saat sedang ujian semester. Sedangkan kecemasan sedang pada saat perkuliahan berjumlah 3 orang, ringan 29 orang, dan tidak ada kecemasan 68 orang dengan rerata 11.75 dengan standart deviasi 4.59 dimana hal ini menunjukkan tidak adanya kecemasan yang tinggi pada mahasiswa jurusan fisioterapi poltekkes
Kemenkes Jakarta III saat sedang perkuliahan, jika dibandingkan dengan saat ujian rerata tingkat stress meningkat, dikarenakan tekanan saat ujian dan tugas serta mahasiswa takut jika mendapat indeks prestasi yang rendah, sehingga mempengaruhi tingkat stress mahasiswa.

Setelah dilakukan analisis deskriptif pada masing-masing variable yang akan diteliti selanjutnya diuji terlebih dahulu normalitas dari variabel jenis Kelamin, Kebiasaan Olahraga, dan Tingkat Stress sebelum dilakukan analisis bivariat lebih lanjut. Hasil uji normalitas tersaji pada tabel 5.5 di bawah ini.

Tabel 5 Uji Normalitas Variabel Dependent dan Independent dengan Metode Shapirowilk

\begin{tabular}{lll}
\hline Uji Normalitas & \multicolumn{2}{c}{ Shapiro-Wilk } \\
\cline { 2 - 3 } & Statistik & Signifikansi(p) \\
\hline Jenis Kelamin & 0.50 & $0.01^{*}$ \\
\hline Kebiasaan Olahraga Ujian & 0.93 & $0.01^{*}$ \\
\hline Kebiasaan Olahraga Perkuliahan & 0.91 & $0.01^{*}$ \\
\hline Tingkat Stress Ujian & 0.90 & $0.01^{*}$ \\
\hline Tingkat Stress Perkuliahan & 0.93 & $0.01^{*}$ \\
\hline
\end{tabular}

** $\mathrm{p}<0.05$ data tidak berditribusi normal

Berdasarkan perhitungan uji normalitas dengan menggunakan metode ShapiroWilk diketahui data variabel jenis kelamin, kebiasaan olahraga, dan tingkat stress, berdistribusi tidak normal sehingga perlu dilakukan uji non-parametrik variabel bersifat ordinal yaitu uji spearmen untuk menguji hubungan masing-masing variabel. Sedangkan untuk mengetahui adanya hubungan perubahan kebiasaan olahraga, dan tingkat stress pada saat ujian dan perkuliahan digunakan uji non parametrik Wilcoxon.

2. Hubungan Kebiasaan Olahraga saat ujian dan perkuliahan Dengan Tingkat Stress Saat Ujian Dan Saat Perkuliahan. 
Uji korelasi masing-masing variabel dilakukan antara variabel kebiasaan ditunjukkan pada tabel 5.6. Uji korelasi olahraga terhadap variabel tingkat stress.

Tabel 6. Hubungan Kebiasaan OlahragaDengan Tingkat Stress Saat Sedang Ujian

\begin{tabular}{lllll}
\hline & \multicolumn{2}{l}{$\begin{array}{l}\text { Kebiasaan Olahraga Saat } \\
\text { Ujian }\end{array}$} & \multicolumn{2}{l}{$\begin{array}{l}\text { Kebiasaan Olahraga Saat } \\
\text { Perkuliahan }\end{array}$} \\
\cline { 2 - 6 } & $\mathbf{r}$ & $\mathbf{p}$ & $\mathbf{r}$ & $\mathbf{p}$ \\
\hline Tingkat Stress Saat Ujian & 0.312 & 0.002 & 0.241 & 0.016 \\
\hline $\begin{array}{l}\text { Tingkat Stress Saat } \\
\text { Perkuliahan }\end{array}$ & 0.168 & 0.095 & -0.231 & 0.021 \\
** $\mathrm{p}<0.05$ terdapat hubungan yangsignifikan & & &
\end{tabular}

Berdasarkan uji statistik Spearmen Correlation Coefficient untuk variabel kebiasaan olahraga saat ujian dengan tingkat stress saat ujian mempunyai korelasi sebesar $r=0,312$, dan terdapat hubungan yang signifikan $\mathrm{p}=0,002$, sedangkan hubungan kebiasaan olahraga saat ujian dengan tingkat stress saat perkuliahan didapati korelasi sebesar 0.168 , dengan $\mathrm{p}=0.095$ tidak terdapat hubungan yang signifikan. Sementara jika dibandingkan dengan kebiasaan olahraga saat perkuliahan dengan tingkat stress saat ujian terdapat houngan yang signifikan $\mathrm{p}=0.016$ dan terdapat korelasi positif sebesar $r=0.241$, yang mana terdapat hubungan searah antara kebiasaan olahraga dan tingkat stress, sedangkan sebaliknya kebiasaan olahraga saat perkuliahan dengan saat perkuliahan terdapat yang mana terdapat hubungan yang berlawanan dikarenakan bahwa jika terdapat nilai rerata kebiasaan olahraga meningkat hal ini akan menyebabkan tingkat stress menurun dengan nilai koefisien korelasi sebesar $r=-0,23$, hal ini menunjukkan terdapat tingkat hubungan yang sedang dan hubungan antara variable kebiasaan olahraga dengan tingkat stress dengan $\mathrm{p}<0.05$ yang bermakna bahwa terdapat hubungan yang signifikan dengan $\mathrm{p}=0.02$.

3. Hubungan Jenis Kelamin dengan tingkat Stress

Berdasarkan tabel 5.7 hasil uji statistik Mann Whitney U Test untuk variabel jenis kelamin dengan tingkat stress saat sedang ujianterdapat korelasi negatif antara jenis kelamin dan tingkat stresssaat ujian maupun saat perkuliahan yang mana terdapat hubungan yang berlawanan arah, dengan nilai $Z$ sebesar -0.50pada saat ujian dan nilai $\mathrm{Z}$ sebesar -0.49 pada saat perkuliahan, dimana didapatkan nilai $\mathrm{Z}$ lebih besar dari $\mathrm{Z}$ tabel $=0.291$ maka hal 
ini menunjukkan terdapat perbedaan tingkat stress antara perempuan dengan laki-laki dan hubungan antara variable jenis kelamin dengan tingkat stress dengan p >0.05 yang bermakna bahwa tidak terdapat hubungan yang signifikan.

Tabel 7. Uji Hubungan Jenis KelaminDengan Tingkat Stress Saat Ujian Dan Perkuliahan

\begin{tabular}{lll}
\hline & Jenis Kelamin & \\
\hline Tingkat Stress Ujian & $\mathrm{Z}=-0.50$ & $\mathrm{p}=0.61 * *$ \\
\hline Tingkat Stress Perkuliahan & $\mathrm{Z}=-0.49$ & $\mathrm{p}=0.62$ \\
\hline
\end{tabular}

** $\mathrm{p}>0.05$ tidak terdapat hubungan yang signifikan

\section{Pembahasan Hasil Penelitian}

Stress sudah menjadi istilah dan seolah menjadi bagian hidup sehari-hari. Dikejar batas waktu menyelesaikan pekerjaan atau kegiatan rumah tangga atau tuntutan prestasi dalam olah raga atau sekolah, menyebabkan stress.Hasil penelitian menunjukkan bahwa kebiasaan olahraga dapat mempengaruhi tingkat stress, hal ini sesuai dengan penelitian yang dilakukan oleh (Wike H, 2015), yang berjudul "Relationship Between Physical Activity, Psychological Well-Being, And Stress In A College Population" menunjukkan bahwa aktivitas fisik, serta olahraga yang cukup akan berdampak pada tingkat stress mahasiswa.

Pada Penelitian ini didapati jumlah responden laki-laki berjumlah 21 orang, dan jumlah perempuan berjumlah 79 orang dari total 100 responden, dengan demikian perempuan lebih banyak dibandingkan laki-laki, hal ini juga sejalan dengan penelitian yang dilakukan oleh (Kinner VL et al, 2014) bahwa perempuan lebih banyak mengalami stress dibandingkan laki-laki. Rerata usia responden yaitu 20,48 tahun dengan usia terendah 18 tahun dan tertinggi 22 tahun.

Rerata kebiasaan olahraga saat perkuliahan sebesar 22,87 $(\mathrm{SD}=2.79)$ sedangkan rerata kebiasaan olahraga saat ujian berjumlah 22,57 (SD = 2.94), dimana hal ini menunjukkan rerata kebiasaan olahraga saat perkuliahan lebih tinggi, dikarenakan pada saat perkuliahan mahasiswa lebih mempunyai banyak waktu dibandingkan saat ujian. Rerata tingkat stress saat perkuliahan berjumlah $11.75(\mathrm{SD}=4.59)$ dan rerata tingkat stress saat ujian berjumlah 12.12 (SD = 5.11), hal ini menunjukkan bahwa mahasiswa saat mereka ujian tingkat stress meningkat, disebabkan karena tugas, waktu belajar 
yang meningkat, serta kekhawatiran akan kelulusan saat ujian.

Dari hasil penelitian kebiasaan olahraga dengan tingkat stress didapat nilai kebiasaan olahraga saat ujian dengan tingkat stress saat ujian mempunyai korelasi sebesar $r=0,312$, dan terdapat hubungan yang signifikan $\mathrm{p}<0.05$, sedangkan hubungan kebiasaan olahraga saat ujian dengan tingkat stress saat perkuliahan didapati korelasi sebesar 0.168, dengan $\mathrm{p}>0.05$ tidak terdapat hubungan yang signifikan. Sementara jika dibandingkan dengan kebiasaan olahraga saat perkuliahan dengan tingkat stress saat ujian terdapat hubungan yang signifikan $\mathrm{p}<0.05$ dan terdapat korelasi positif sebesar $r=0.241$, yang mana terdapat hubungan searah antara kebiasaan olahraga dan tingkat stress, sedangkan sebaliknya kebiasaan olahraga saat perkuliahan dengan saat perkuliahan terdapat yang mana terdapat hubungan yang berlawanan dikarenakan bahwa jika terdapat nilai rerata kebiasaan olahraga meningkat hal ini akan menyebabkan tingkat stress menurun dengan nilai koefisien korelasi sebesar $r=-0,23$, hal ini menunjukkan terdapat tingkat hubungan yang sedang dan hubungan antara variable kebiasaan olahraga dengan tingkat stress dengan $\mathrm{p}<0.05$ yang bermakna bahwa terdapat hubungan yang signifikan dengan $\mathrm{p}=0.02$, dimana hal ini menunjukkan adanya perubahan bermakna, dan terdapat hubungan yang searah, hal ini dipengaruhi oleh kebiasaan mahasiswa jurusan fisioterapi dalam hal berolahraga, diketahui bahwa mahasiswa jurusan fisioterapi, sering melakukan kegiatan olahraga seperti, footsal, basket, volley untuk laki-laki, sedangkan perempuan cenderung mengikuti olahraga seperti berenang, lari pagi pada hari libur, sehingga mempengaruhi tingkat stress mereka, pada saat sedang ujian tingkat stress meningkat dikarenakan factor ekstrenal dari lingkungan, seperti teman, dosen, instruktur, mahasiswa mengalami pressure stress dikarenakan mereka mendapat tugas, dan belajar pada saat siang, dan malam agar hasil dari ujian akan membuat indeks prestasi mereka baik.

Sedangkan hasil penelitian dari (Edman, J. L etal, 2014) diketahui bahwa jenis kelamin dapat mempengaruhi tingkat stress seseorang yaitu tingkat stres yang lebih tinggi sering dijumpai pada perempuan.Penelitian lain menyebutkan bahwa untuk setiap kriteria jenis kelamin dengan tingkat stres antara laki-laki dan perempuan sama. Hal ini berbeda pada perempuan dimana mereka lebih mudah merasakan cemas, perasaan bersalah, gangguan tidur, serta gangguan makan. 
Hal ini sejalan dengan penelitian yang dilakukan dimana sampel lebih dominan perempuan sebesar $79 \%$ tetapi hal ini tidak memiliki kaitan signifikan dimana $\mathrm{P}$ $>0.05$, sedangkan secara hubungan didapatkan nilai $\mathrm{Z}=-0.50$ saat ujian dan $\mathrm{Z}=-0.49$ saat perkuliahan, dimana hal ini menandakan bahwa terdapat perbedaan antara perempuan dengan laki-laki terhadap tingkat stress baik saat ujian maupun saat perkuliahan.

Sebuah penelitian yang dilakukan terhadap 2.700 orang laki-laki dan perempuan yang belum mengalami depresi. Selama kurun waktu 2008 sampai 2011. Setelah satu tahun, ternyata para peserta ini mengalami tingkat depresi yang cukup tinggi. Sebanyak 3,6 persen peserta mengalami depresi karena pekerjaannya. Insiden peningkatan depresi akibat pekerjaan ini ternyata lebih banyak dialami perempuan sampai sekitar 4,5 persen, sedangkan lakilaki hanya 2,9 persen saja. Hal ini menunjukkan, lingkungan dan kondisi pekerjaan bisa mempengaruhi kesehatan mental seorang pekerja, baik laki-laki maupun perempuan, namun dengan cara yang berbeda.

Menurut penelitian ini, penyebab perempuan mengalami stres biasanya karena kurangnya penghargaan di tempat kerja, atau tidak dihargai atas upaya dan kerja keras yang dilakukannya. Sedangkan pria lebih banyak merasakan stres akibat pekerjaan yang menumpuk sehingga membuat mereka tegang. (Kinner V.L et al, 2014).

Olahraga yang baik akan dapat mengurangi stress hal ini dikarenakan, olahraga dapat merangsang feel good hormone yaitu endorphin, hormone ini akan memberikan rasa tenang, melepaskan ketegangan, dan mengurangi rasa sakit. Endorphin yang dihasilkan selama berolahraga akan menggantikan hormone stress dan membuat emosi lebih stabil. Dan sebaliknya jika sesorang jarang melakukan kegiatan olahraga maka tingkat sressnya akan meningkat hal ini sejalan dengan meningkatnya hormone stress yaitu kortisol (Stevens, R.E et al, 2013).

Melakukan aktivitas fisik dengan berolahraga setiap hari merupakan bagian dari hidup sehat. Berolahraga setiap hari memberikan manfaat besar bagi remaja seperti meningkatkan energi, dan mencegah datangnya penyakit kronis. Tidak hanya orang dewasa saja yang perlu membiasakan diri untuk olahraga. Anakanak dan remaja juga perlu melakukan hal yang sama, apalagi ini akan membantu mengoptimalkan tumbuh kembangnya. Olahraga juga dapat membantu mempromosikan kesehatan mental yang 
baik pada anak-anak dan remaja(Gaetano $\mathrm{R}$ et al, 2015).

Kesehatan mental mencakup kemampuan kita untuk berpikir, merasa, bertindak, dan berinteraksi dalam cara-cara yang memungkinkan untuk mengatasi tantangan sambil menikmati hidup. Pada anak-anak dan remaja, kesehatan mental berkaitan dengan perkembangan sosial dan emosional yang sehat di mana mereka belajar untuk mengalami, mengatur, dan mengekspresikan berbagai emosi. Kesehatan mental yang positif pada anakanak dan remaja memungkinkan mereka untuk menjadi kreatif, lebih bisa berinteraksi secara sosial, dan berani mencoba hal baru.

Banyak faktor yang bisa merusak kesehatan mental seorang anak. Salah satunya, masa peralihan seorang anak menjadi remaja dihadapkan dengan berbagai tantangan yang berkaitan dengan pubertas, perubahan peran sosial dan lingkungan yang mengiringi proses pendewasan. Hal-hal tersebut bisa memicu masalah perilaku dan stres berkepanjangan. Seiring perkembangan zaman, pengaruh era digital membuat banyak remaja lebih senang bermain game di gadget atau lebih aktif di jejaring sosial ketimbang aktif bergerak. Ini juga membuat remaja mudah tertekan dan rentan stress (Segerstrom,S.C et al, 2004)
Terlibat dalam olahraga telah terbukti efektif dalam meningkatkan kesehatan mental anak dan remaja. Berdasarkan sejumlah penelitian, olahraga bisa membantu melawan stres, kecemasan, dan depresi. Semakin rutin dilakukan, semakin kecil kemungkinan seseorang menderita masalah kesehatan mental tersebut. Saat melakukan aktivitas fisik, tubuh memproduksi hormon-hormon tertentu yang membuat suasana hati lebih baik dan tubuh menjadi lebih rileks. Kualitas tidur juga akan semakin baik. Olahraga juga membantu meningkatkan performa akademik.

Penelitian yang diterbitkan dalam Journal of Abnormal Psychology melaporkan bahwa partisipasi olahraga dan aktivitas fisik dalam porsi yang lebih tinggi terkait dengan tingkat depresi yang lebih rendah, serta persepsi diri yang lebih baik. Ini benar-benar bermanfaat bagi remaja perempuan. Remaja perempuan dianggap lebih rentan mengalami depresi daripada remaja laki-laki pada usia yang sama.(Nguyen-Michel et al, 2006).

Studi lain dari Trimbos Institute semakin menambah manfaat olahraga untuk kesehatan mental. Tim peneliti telah mengindentifikasi hubungan antara olahraga dan kesehatan mental pada 7.000 remaja yang berusia 11 hingga 16 tahun. Dalam akhir penelitian tersebut, 
dilaporkan bahwa remaja yang rajin berolahraga cenderung memancarkan citra diri yang positif dan memiliki kemampuan berinteraksi sosial yang baik.

Sejalan dengan itu, tim peneliti dari University of Dundee dan University of Strathclyde menemukan bahwa aktivitas fisik menawarkan manfaat dalam pencapaian di bidang ilmu pengetahuan. Penelitian ini melibatkan sekitar 5.000 anak-anak, ditemukan hubungan antara olahraga dan keberhasilan ujian dalam bahasa Inggris, matematika, dan sains. Ditemukan peningkatan kinerja akademik untuk setiap tambahan 17 menit berolahraga pada anak laki-laki dan 12 menit pada anak perempuan (Budd, S.C et al., 2017).

Remaja harus terlibat dalam aktivitas fisik setidaknya 60 menit setiap hari. Ini bisa terdiri dari aktivitas fisik yang bervariasi dan tidak harus dilakukan sekaligus. Kuncinya adalah tetap aktif. Selain terlibat dalam kelas olahraga disekolah, jalan kaki, renang, jogging dan bersepeda di sekitar rumah juga bisa menjadi pilihan olahraga bagi anak-anak dan remaja yang bisa dilakukan bersama keluarga.

\section{SIMPULAN}

Kebiasaan olahraga yang baik berpengaruh signifikan terhadap tingkat stress, dikarenakan menurunnya hormone stress, dan meningkatnya feel good hormone, kebiasaan olahraga saat ujian tidak berpengaruh terhadap tingkat stress saat perkuliahan. Terdapat perbedaan tingkat stress antara laki-laki dan perempuan, jumlah responden lebih banyak wanita.Tidak terdapat hubungan yang signifikan antara jenis kelamin dengan tingkat stress.

\section{DAFTAR RUJUKAN}

Budd,S.C, J.-C. Egea, (2017). The Popularity and Benefits of Sport and Exercise: Implications in Dentistry. Sport and Oral Health, DOI 10.1007/978-3-319-53423-7_2.

Dahlan, MS (2014), Statistik untuk Kedokteran dan Kesehatan: Deskriptif, Bivariat, dan Multivariat, Dilengkapi Aplikasi Menggunakan SPSS, 6ed, Epidemiologi Indonesia, Jakarta.

Edman, J. L., Lynch, W. C., Yates, A. (2014). The impact of exercise performance dissatisfaction and physical exercise on symptoms of depression in college students: sexcomparison. Journal of Psychology, 148, 23-25.Retrieved fromhttp:// www . ncbi . nlm . nih . gov

.resources.library.brandeis.Edu/pub med/24617269.

Ichraf A, Ali B M, Khaled T, Liwa M, Elloumi A (2013). Effect of gender and type of sport on anxiety and selfesteem., International Journal of Humanities and Social Science Invention ISSN (Online): 2319 7722, ISSN (Print): 2319 - 7714 
www.ijhssi.org Volume 2 Issue $3 \|$ March. 2013\| PP.55-61.

Kenari, M.A. (2014), Effect of Exercise on Mental Health in the Physical Dimension.

Kinner V.L, Serkan Het and Oliver T. Wolf. (2014), Emotion regulation: exploring the impact of stress and sex. Frontiers in Behavioral Neuroscience, Original Research Article, November 2014 | Volume 8 | Article 397.

Knechtle, B. (2004), Influence of Physical Activity on Mental Well-Being and Psychiatric Disorders. Schweiz Rundsch Med Prax, 93, 1403-1411.

Matsudo, S. (2006), Evaluation of a Physical Activity Promotion Program: The Example of Agita São Paulo. Evaluation and Program Planning, 29, 301-311.

Nguyen-michel, S. T., Unger, J. B., Hamilton, J., \& Spruijt-metz, D. (2006). Associations between physical activity and perceived stress / hassles in college students, 188(August 2005), 179-188.

Pereira, A. C. (2007), An in Vivo Correlate of Exercise-Induced Neurogenesis in the Adult Dentate Gyrus. Proceedings of the National Academy of Sciences of the United States of America, 104, 5638-5643.

PROMKES. (2009), Departemen Kesehatan Republik Indonesia. Jakarta - Indonesia. Lakukan Kebiasaan Fisik 30 Menit Sehari. Copyright @February 1, 2009 webmaster@promosikesehatan.com.
Raiola G, F Gomes Taloma, Altavilla, G., (2014). Anxiety in the Youth Physical and Sport Activity by Mediterranean Journal of Social Sciences, Vol 6 No 3 S2 May 2015; ISSN 2039-2117 (online).

Riskesdas (2013), Laporan Nasional Badan Penelitian dan Pengembangan Kesehatan Departemen Kesehatan, Republik Indonesia Desember.

Salmon P. (2001). Effects of Physical Exercise on Anxiety, Depression and Sensitivity to Stress - A Unifying Theory . ANXIETY , DEPRESSION , AND SENSITIVITY TO STRESS: A UNIFYING THEORY, 21, 33-61.

Segerstrom, S.C., \& Miller, G. E. (2004). Psychological stress and the humanimmune system: A metaanalytic study of 30 years of inquiry.PsychologicalBulletin, 130(4), 601-630.

Singgih Santoso. (2009), Panduan lengkap menguasai SPSS 17. Jakarta. Penerbit : PT Elex Media Komputindo.

Stevens, R. E., Loudon, D. L., Yow, D. A., Bowden, W. W., \& Humphrey, J. H.(2013).Stress in college athletics: Causes, consequences, coping. Routledge.

Wike K.H. (2015). Examining The Relationship Between Physical Activity, Psychological Well-Being, And Stress In A College Population, A Thesis Submitted to the Faculty of the University of Tennessee at Chattanooga in Partial Fulfillment of the Requirements of the Degree of Master of Science: Psychology. 